\title{
RELEVANTTA LUI WALTER \\ LIPPMANN PENTRU SENSUL \\ ATRIBUIT SECURITĂȚII \\ DE CĂTRE ARNOLD WOLFERS
}

\author{
Dr. Alexandru LUCINESCU*
}

În prezent, definiția securității formulată, în 1952, de Arnold Wolfers în articolul „Securitatea națională ca un simbol ambiguu” este frecvent citată în domeniul studiilor de securitate, în timp ce definiția acestui concept, propusă de Walter Lippmann într-o carte din 1943, intitulată „Politica externă a SUA: scutul republicii", este în mare parte absentă din acest domeniu, o situație care nu facilitează analizarea conexiunilor dintre aceste definiții. Cu toate acestea, sunt autori care citează atât definiția securității formulată de Wolfers, cât și definiția acestui concept elaborată Lippmann, dar aceștia fie nu menționează existența unor conexiuni între cele două definiții, fie le remarcă dar nu le investighează, motiv pentru care nu a fost realizată încă o analiză detaliată a acestei probleme. Pentru a elimina această lacună din studiul primelor etape ale dezvoltării studiilor de securitate, în acest articol este realizată o analiză aprofundată a legăturilor de natură logică dintre cele două definiții ale securității, iar concluzia acestui demers este aceea că reflecția lui Wolfers asupra securității a avut rolul de a explica aspecte implicite ale definiției acestui concept formulată de Lippmann, dar că în cele din urmă, și, într-un anumit sens, în mod neintenționat, Wolfers a propus o altă definiție a securității.

Cuvinte-cheie: Walter Lippmann; Arnold Wolfers; definiția securității; studii de securitate; realism; politică externă.

* Dr. Alexandru LUCINESCU este conferențiar universitar în cadrul Facultății de Securitate și Apărare din Universitatea Națională de Apărare „Carol I”, București. E-mail: alucinescu@gmail.com 


\section{Introducere}

Relevanța pe care definiția securității propusă de Walter Lippmann într-o carte a sa din 1943, Politica externă a SUA: scutul Republicii, o are pentru bine-cunoscuta definiție a securității propusă de Arnold Wolfers în articolul său Securitatea națională ca simbol ambiguu, care a fost publicat în 1952, constituie tema acestui articol. Alegerea temei este justificată de faptul că relația dintre definițiile menționate reprezintă, în general, o problemă neglijată, iar atunci când este remarcată, ea nu este explicată sau analizată în detaliu, motiv pentru care relația dintre cele două definiții nu a făcut obiectul unui studiu aprofundat. Această evaluare se bazează pe o analiză a literaturii de specialitate din 1983 și până în prezent, analiză care, împreună cu formularea și justificarea importanței temei de cercetare și a întrebării de cercetare și cu descrierea metodelor de cercetare utilizate, constituie secțiunea referitoare la aspectele metodologice ale acestui articol. Cea de-a doua secțiune a sa constă în analizarea și interpretarea sensului pe care Lippmann îl atribuie securității în cartea menționată anterior, iar în ultima secțiune a articolului, modul în care Lippmann înțelege securitatea este discutat în contextul articolului lui Wolfers, perspectiva lui Wolfers asupra acestei definiții este prezentată în detaliu și punctele de vedere ale celor doi autori cu privire la definiția securității sunt comparate atât din punctul de vedere al lui Wolfers, cât și dintr-un punct de vedere obiectiv.

\section{Considerații metodologice}

Autorii care au indicat contribuția pe care Water Lippmann și/sau Arnold Wolfers au avut-o la definirea conceptului de securitate, fie nu s-au referit la relevanța pe care viziunea lui lui Lippmann asupra securităţii o are pentru perspectiva lui Wolfers asupra acestui concept, fie au menționat acest lucru, dar nu l-au analizat. Astfel, în anii '80, în prima ediție a lucrării Popoarele, statele și frica, Barry Buzan a citat succesiv definiția dată securității de Lippmann în Politica externă a SUA: scutul republicii și definiția formulată pentru acest concept de Wolfers în articolul Securitatea națională ca un simbol ambiguu ${ }^{1}$. Citatul preluat din Lippmann este următorul: „o națiune dispune de securitate în măsura în care nu este în pericol de a fi nevoită să își sacrifice valorile fundamentale pentru a evita un război și este capabilă, dacă este amenințată, să le păstreze prin obținerea unei victorii într-un război purtat pentru apărarea lor", în timp ce fragmentul din Wolfers este următorul: „securitatea, într-un sens obiectiv, măsoară absența amenințărilor la adresa valorilor

\footnotetext{
${ }^{1}$ Barry Buzan, People, States, and Fear. The National Security Problem in International Relations, p. 216, Brighton, Wheatsheaf Books, 1983. Citatul din Wolfers este preluat din colecția sa de eseuri intitulată Discord and Collaboration care include și acest articol. (Arnold Wolfers, Discord and Cooperation. Essays on International Politics, Baltimore, The John Hopkins Press, 1962).
} 
dobândite, iar într-un sens subiectiv, absența fricii că aceste valori vor fi atacate". Deși Buzan precizează că definiția propusă de Lippmann a fost preluată din cartea lui Wolfers, el nu stabilește nicio legătură între aceste definiții. În cea de-a doua ediție a cărții sale, care a fost publicată după sfârșitul Războiului Rece, Buzan a avut o abordare similară a celor două definiții cu singura diferență că acestea nu mai figurează una după cealaltă, ci sunt separate de definiții ale securității propuse de alți autori. ${ }^{2,3}$

Tot în anii '80, Mohammed Ayoob a pus în evidență faptul că definiția dată securității de Lippmann în lucrarea menționată a fost discutată de Wolfers în celebrul său articol și că Wolfers a înțeles această definiție ca referindu-se la capacitatea unui stat de a descuraja sau de a se apăra de un atac îndreptat împotriva sa. Cu toate acestea, Ayoob nu a analizat implicațiile definiției propuse de Lippmann asupra concepției lui Wolfers despre securitate. Se remarcă faptul că Ayoob nu a preluat din articolul lui Wolfers definiția propusă de Lippmann, așa cum a procedat Buzan, ci chiar din lucrarea Politica externă a SUA: scutul republicii, ${ }^{4}$ astfel încât nu mai există niciun indiciu al existenței unei legături între definițiile formulate de cei doi autori.

Existența unei legături între definiția dată securităţii de Wolfers în Securitatea națională ca simbol ambiguu și definiția securității formulată de Lippmann în Politica externă a SUA: Scutul Republicii, a fost remarcată de Graham M. Smith care, într-un articol din 2005, a arătat că Wolfers ,utilizează ideile lui Walter Lippmann"`. Deși a observat existența unei legături între cele două definiții, Smith nu a analizat-o, astfel încât sensul afirmației sale este unul imprecis; se poate spune că Smith a indicat o direcție de cercetare, dar nu a urmat-o. Se observă că Smith nu menționează faptul că Wolfers îl citează pe Lippmann și nici nu face vreo referire la cartea acestuia din urmă. Cu toate acestea, având în vedere că Politica externă a SUA: scutul republicii este menționată în articolul lui Wolfers, este justificat să se considere că Smith semnalează, în mod implicit, existența unei legături între aceste lucrări.

Observația lui Smith nu se regăsește însă în cartea din 2021 a lui Columba Peoples și Nick Vaughan-Williams, care oferă o introducere în domeniul studiilor critice de securitate, și aceasta cu toate că aici este indicată contribuția la definirea ${ }^{2}$ Ibidem, p. 216.

${ }^{3}$ Barry Buzan, People, States, and Fear. An Agenda for International Security Studies in the PostCold War Era, p. 36, Colchester, ECPR Press, 2009.

${ }^{4}$ Mohammed Ayoob, „Security in the Third World: the worm about to turn?”, în International Affairs, vol. 60, nr.1, 1984, pp. 41-51. Similar lui Buzan, Ayoob face referire la articolul Securitatea națională ca simbol ambiguu, inclus în colecția de eseuri a lui Wolfers Discord and Collaboration.

${ }^{5}$ Graham M. Smith, „Into Cerberus' Lair: Bringing the Idea of Security to Light”, p. 489, în British Journal of Politics and International Relations, vol. 7, nr. 4, pp. 485-507; versiunea originară a citatului este următoarea „draws on the thought of Walter Lippmann”. 
conceptului de securitate pe care au avut-o atât Lippmann, prin lucrarea sa din 1943, cât și Wolfers, prin intermediul articolului său din 1952. Peoples şi VaughanWilliams nu abordează problema legăturii dintre ideile despre securitate ale celor doi autori și nici măcar nu indică faptul că Lippmann este unul dintre autorii menționați de Wolfers, astfel încât nu sunt oferite elemente care să indice o posibilă conexiune între ideile lor. ${ }^{6}$

În multe lucrări recente care pot fi considerate ghiduri în domeniul studiilor de securitate, contribuția lui Lippmann la definiția securităţii, spre deosebire de cea a lui Wolfers, nu mai este recunoscută, astfel încât devine imposibil să se ia în considerare varianta ca Wolfers să fi fost influențat de Lippmann în formularea definiției securității care figurează în articolul său Securitatea națională ca un simbol ambiguu. $\mathrm{Cu}$ titlu de exemplu, pot fi amintite Manualul de studii de securitate din 2010, coordonată de Myriam Dunn Cavelty și Victor Mauer ${ }^{7}$, Crestomația pentru studii de securitate, coordonată în 2011 de Christopher W. Hughes și Lai Yew Meng ${ }^{8}$, Manualul de studii de securitate din 2017, ai cărui coordonatori sunt Myriam Dunn Cavelty și Thierry Balzacq ${ }^{9}$, Introducerea în domeniul studiilor de securitate, editată în 2018 de Paul D. Williams și Matt McDonald ${ }^{10}$ și cartea din 2021 privind aspectele teoretice și practice ale studiilor internaționale de securitate, ai cărei coautori sunt Peter Hough, Andrew Moran, Bruce Pilbeam și Wendy Stokes ${ }^{11}$; în toate aceste lucrări este menționată doar contribuția pe care Wolfers, prin intermediul articolului Securitatea națională ca un simbol ambiguu, a avut-o la definirea conceptului de securitate.

Lippmann nu este menţionat în influentul articol din 1997 al lui David Baldwin despre conceptul de securitate unde se arată, însă, că Wolfers, în articolul menționat, a conceput securitatea ca pe „absența amenințărilor la adresa valorilor dobândite" și i-a atribuit atât un sens obiectiv, cât și unul subiectiv. ${ }^{12}$ Lippmann este absent și dintr-o carte din 2009 a lui Barry Buzan și Lene Hansen, care reconstituie

\footnotetext{
${ }^{6}$ Columba Peoples, Nick Vaughan-Williams, Critical Security Studies. An Introduction, ediția a 3-a, pp. 2, 5, Londra, Routledge, 2021.

${ }^{7}$ Myriam Dunn Cavelty; Victor Mauer, „Introduction”, în Myriam Dunn Cavelty; Victor Mauer (coord.), The Routledge Handbook of Security Studies, Londra, Routledge, 2010, p. 2.

${ }^{8}$ Christopher W. Hughes, Lai Yew Meng (coord.), Security Studies. A Reader, London, Routledge, 2011, p. 1.

${ }^{9}$ Myriam Dunn Cavelty, Thierry Balzacq, „Introduction”, in Myriam Dunn Cavelty; Thierry Balzacq (coord.), Routledge Handbook of Security Studies, ediția a 2-a Londra, Routledge, 2017, p. 1.

${ }^{10}$ Matt McDonald, „Constructivism”, în Paul D. Williams, Matt McDonald (coord.), Security Studies. An Introduction, ediția a 3-a, Londra, Routledge, 2018, p. 50.

${ }^{11}$ Edward Smith, „The Traditional Routes to Security. Realism and Liberalism”, în Peter Hough, Andrew Moran, Bruce Pilbeam, Wendy Stokes (coord.), International Security Studies. Theory and Practice, ediția a 2-a, Londra, Routledge, 2021, p. 15.

${ }_{12}$ David Baldwin, ,The Concept of Security”, p. 13, în Review of International Studies, vol. 23, nr. 1, pp. 5-26, 1997.
} 
evoluția studiilor internaționale de securitate, o carte în care figurează, în schimb, distincția operată de Wolfers în acel articol între sensul obiectiv și cel subiectiv al securității ${ }^{13}$; având în vedere că această carte plasează începuturile studiilor de securitate internațională în anii ' 40 și că lucrarea lui Lippmanna fost publicată în 1943, se deduce că, în opinia lui Buzan și a lui Hansen, Lippmann, spre deosebire de Wolfers, nu a avut o contribuție relevantă la dezvoltarea conceptului de securitate și nu a exercitat vreo influență asupra sensului atribuit securității de Wolfers.

Chiar dacă, în prezent, relevanța concepției despre securitate a lui Lippmann pentru modul în care Wolfers înțelege acest concept nu este o temă de cercetare, faptul că definiția dată securității de Lippmann a fost citată și comentată de Wolfers în celebrul său articol și faptul că Smith consideră că Wolfers a fost influențat de perspectiva lui Lippmann asupra securității, justifică realizarea unei cercetări pe această temă. Un alt argument în favoarea realizării unui asemenea demers rezultă din analizarea atentă a articolului lui Wolfers, dat fiind că aceasta relevă faptul că referirile la Lippmann sunt incluse în paragraful care precede paragraful în care se face distincția între sensul obiectiv și sensul subiectiv al securității. Relevanța științifică a acestei teme este susținută și de faptul că, în Polul puterii și polul Indiferenței, un articol al lui Wolfers, care a apărut cu un an înainte de publicarea articolului Securitatea națională ca un simbol ambiguu, acesta a susținut că o politică externă prudentă impune oamenilor de stat să urmărească numai obiective care sunt realizabile prin intermediul puterii de care dispune statul pe care îl conduc sau pe care acesta ar putea să o dobândească și a precizat că această idee constituie teza centrală a cărții lui Lippmann Politica externă a SUA: scutul republicii ${ }^{14}$. În sprijinul viabilității acestei teme de cercetare poate fi menționat și faptul că atât Lippmann, cât și Wolfers aparțin școlii realiste din domeniul relațiilor internaționale ${ }^{15}$ și că, la doi ani după publicarea articolului Securitatea națională ca un simbol ambiguu, Lippmann și Wolfers au explorat împreună posibilitatea elaborării unei teorii a relațiilor internaționale. ${ }^{16}$

Se poate aprecia că, pentru domeniul studiilor de securitate, această temă este foarte importantă deoarece definiția securității propusă de Wolfers este una

\footnotetext{
${ }^{13}$ Barry Buzan, Lene Hansen, The Evolution of International Security Studies, Cambridge, Cambridge University Press, 2009, pp. 32-33.

14 Arnold Wolfers, „The Pole of Power and the Pole of Indifference”, p. 48, in World Politics, vol. 4, nr. 1, 1951, pp. 39-63. Acest articol este inclus, alături de „National Security as an Ambiguous Symbol", în colecția de eseuri ale lui Wolfers, Discord and Cooperation.

${ }^{15}$ Robert E. Williams Jr., „The Invention of International Relations Theory: Realism, the Rockefeller Foundation, and the 1954 Conference on Theory, Edited by Nicolas Guilhot", p. 284, în Ethics and International Affairs, vol. 26, nr. 2, 2012, pp. 284-286.

${ }^{16}$ Nicolas Guilhot (coord.), The Invention of International Relations Theory: Realism, the Rockefeller Foundation, and the 1954 Conference on Theory, p. 239, New York, Columbia University Press, 2011.
} 
consacrată, deoarece indiciile care ar putea direcționa cercetătorii către această temă sunt astăzi aproape inexistente, deoarece până în acest moment această temă nu a făcut obiectul unei cercetări detaliate și, de asemenea, deoarece rezultatele unui astfel de demers permit o mai bună înțelegere a apariției studiilor de securitate și, astfel, contribuie la eliminarea unei carențe din studiul acestui domeniu.

Luând în considerare toate aceste aspecte, întrebării de cercetare care stă la baza articolului de față i se poate da următoarea formulare: Ce influență a avut definiția securităţii propusă de Lippmann în cartea Politica externă a SUA: scutul republicii asupra definiției date de Wolfers acestui concept în articolul Securitatea națională ca un simbol ambiguu? Pentru a răspunde la această întrebare se va realiza o cercetare calitativă prin intermediul căreia metoda analizei de conținut și cea a analizei comparative vor fi utilizate în raport cu secțiunile relevante din cele două lucrări. Mai exact, în cazul cărții lui Lippmann, analiza de conținut vizează paragraful în care este formulată definiția securității, semnificația acestei definiții fiind discutată în relație cu ideea centrală a capitolului căruia îi aparține paragraful respectiv. În ceea ce privește articolul lui Wolfers, analiza de conținut va fi aplicată celor trei paragrafe în care definiția securității este formulată și exemplificată, accentul fiind pus pe modul în care Wolfers utilizează definiția lui Lippmann. Prin intermediul analizei comparative, definiția securitătii inclusă în paragrafele relevante din articolul lui Wolfers este luată în considerare din punctul de vedere al asemănărilor și diferențelor sale în raport cu definiția securității formulată de Lippmann.

\section{Walter Lippmann despre sensul securității}

Lippmann definește securitatea într-un capitol din Politica externă a SUA: scutul republicii, în care exprimă o poziție critică față de politica externă a SUA, despre care afirmă că urmărește pacea în detrimentul securităţii naționale, ceea ce, în opinia sa, este o greșeală, întrucât transformă o iluzie într-un scop primordial ${ }^{17}$. El susține că doar securitatea națională ar trebui să fie un astfel de scop și asociază securitatea națională cu interesele vitale ale unei națiuni, interese pe care le denumește și interese legitime ${ }^{18}$. Potrivit acestei definiții, securitatea înseamnă că un stat este capabil să iși promoveze interesele vitale chiar și în cazul unui război ${ }^{19}$, o idee care, dat fiind că Lippmann consideră războiul ca fiind cea mai dificilă situație cu care se poate confrunta un stat în realizarea intereselor sale vitale, ar putea fi astfel reformulată: un stat dispune de securitate dacă este capabil să își

\footnotetext{
${ }^{17}$ Walter Lippmann, US foreign policy: Shield of the Republic, Boston, Little Brown and Company, 1943, p. 50.

${ }^{18}$ Ibidem, p. 51.

${ }^{19}$ Ibidem.
} 
promoveze interesele vitale în orice circumstanțe, indiferent cât de periculoase sunt acestea. Prin urmare, este posibil să se afirme că, prin stabilirea celui mai înalt standard, Lippmann propune ceea ce s-ar putea numi o perspectivă maximală asupra securității.

Deoarece Lippmann are în vedere asigurarea securității nu doar în timpul războiului, ci și pe timp de pace ${ }^{20}$, rezultă că el consideră riscul izbucnirii unui război ca fiind cel mai mare pericol care poate apărea pe timp de pace la adresa intereselor vitale ale unui stat și că tratează înfrângerea în război ca reprezentând cel mai mare pericol pentru aceste interese atunci când un stat se află în război. Trebuie remarcat faptul că Lippmann apreciază că evaluarea capacității unui stat de a-şi promova interesele vitale în ambele situații trebuie să rezulte dintr-o analiză perfect obiectivă sau, altfel spus, că trebuie să reflecte un nivel de cunoaștere optim; exprimarea lui Lippmann este una foarte explicită în acest sens: ,atât cât este posibil pentru un om să anticipeze și să fie prudent". ${ }^{21}$ Este evident că Lippmann exclude posibilitatea ca o astfel de evaluare să fie doar o impresie, o simplă opinie, susținând, dimpotrivă, că aceasta trebuie să fie cât mai puțin subiectivă sau, altfel spus, atât de obiectivă cât poate fi o evaluare realizată de oameni. Prin urmare, Lippmann propune o înțelegere maximală a naturii obiective a evaluării pe care o implică definiția securității, ceea ce permite să se considere că această definiție este una de tip maximal atât din punctul de vedere al standardului pe care îl presupune, cât și din punctul de vedere al capacității statului de a face față amenințărilor la adresa intereselor sale vitale, deci că definiția respectivă presupune o perspectivă maximală de tip ontologic și o perspectivă maximală de tip cognitiv.

Această analiză arată că nici Buzan și nici Ayoob nu citează corect din Lippmann, având în vedere că acesta afirmă că „o națiune dispune de securitate atunci când nu trebuie să-și sacrifice interesele legitime pentru a evita un război și când este capabilă, dacă este atacată, să le păstreze prin război”"22, în timp ce citatul reprodus de cei doi autori este, așa cum s-a indicat anterior, următorul: „O națiune este în siguranță în măsura în care nu este în pericol de a fi nevoită să își sacrifice valorile fundamentale, dacă dorește să evite războiul, și este capabilă, dacă este atacată, să le păstreze prin obținerea unei victorii într-un război purtat pentru apărarea lor”. Dacă, în cazul lui Buzan, diferențele ar putea fi explicate ca un rezultat al faptului că citatul a fost preluat din articolul lui Wolfers și nu direct din cartea lui Lippmann, nicio explicație viabilă nu poate fi dată pentru existența

${ }^{20}$ Ibidem.

${ }^{21}$ Ibidem.

22 Ibidem. N.A.: În original, cele două citate sunt, în ordine, următoarele: ,a nation has security when it does not have to sacrifice its legitimate interests to avoid war and is able, if challenged, to maintain them by war" și „, nation is secure to the extent to which it is not in danger of having to sacrifice core values, if it wishes to avoid war, and is able, if challenged, to maintain them by such victory in such a war". 
acestor diferențe în cazul lui Ayoob, deoarece acesta indică în mod explicit că a preluat citatul din sursa sa originară, și anume din Politica externă a SUA: scutul republicii. Așadar, se poate spune că și Ayoob a preluat citatul tot din articolul lui Wolfers și că a indicat în mod eronat cartea lui Lippmann ca sursă a acestuia.

Pentru că Lippmann consideră că prudența în domeniul politicii externe înseamnă realizarea de către oamenii de stat a unei potriviri perfecte între obiectivele urmărite de un stat și puterea, exprimată în termeni militari, de care acesta dispune și pentru că, potrivit acestuia, securitatea națională trebuie să fie scopul primordial al fiecărui stat, se poate concluziona, pe de o parte, că Lippmann susține că un stat dispune de securitate numai dacă are, în conformitate cu o evaluare realizată de oameni de stat, care are cel mai înalt grad de obiectivitate de care omul este capabil, puterea necesară pentru asumarea riscului de a duce un război pentru protejarea intereselor sale vitale sau pentru a câștiga un război purtat în acest scop și, pe de altă parte, că asumarea securităţii ca obiectiv de politică externă în situaţia în care statul nu are puterea necesară pentru a-și asuma riscul unui astfel de război sau pentru a câștiga un război reprezintă o imprudență politică. Cu alte cuvinte, trebuie să se considere că, în opinia lui Lippmann, prudența nu permite ca securitatea să poată fi asumată de către orice stat ca un obiectiv de politică externă, ci numai de către acele state care, într-o evaluare având cel mai înalt grad de obiectivitate de care oamenii sunt capabili, dispun de o putere adecvată. Rezultă că Lippmann consideră prudența ca fiind capacitatea care permite oamenilor de stat să facă cele mai obiective evaluări cu privire la capacitatea unui stat de a-și promova interesele vitale atunci când acestea sunt expuse celor mai grave amenințări, deci ca o capacitate care permite oamenilor de stat să evalueze dacă statul dispune sau nu de securitate.

Se observă că definiția dată securității de Lippmann nu a fost remarcată în recenzii ale cărții sale, care au apărut la momentul publicării acesteia, așa cum se constată prin analiza recenziei lui Leland M. Goodrich ${ }^{23}$, a lui James C. Malin ${ }^{24}$ și a celei aparținând lui Mary Sumner Benson. ${ }^{25}$

\footnotetext{
${ }^{23}$ Leland M. Goodrich, „U. S. Foreign Policy: Shield of the Republic by Walter Lippmann”, în The American Political Science Review, vol. 37, nr. 5, 1943, pp. 935-938.

${ }^{24}$ James C. Malin, „U.S. Foreign Policy: Shield of the Republic by Walter Lippmann; America's Foreign Policies, Past and Present by Thomas A. Bailey", în Pacific Historical Review, vol. 12, nr. 4, 1943, pp. 417-418.

${ }_{25}$ Mary Sumner Benson, „U. S. Foreign Policy: Shield of the Republic by Walter Lippmann; Collective Security: The Why and How. by Joseph H. Ball”, în The Far Eastern Quarterly, vol. 3, nr. 3, 1944, pp. 263-265.
} 


\section{Caracteristicile atribuite securității de Arnold Wolfers. O analiză din perspectiva sensului atribuit securității de Walter Lippmann}

În articolul Securitatea națională ca un simbol ambiguu, reflecția lui Wolfers asupra securității pornește de la viziunea lui Lippmann asupra acesteia expusă în lucrarea Politica externă a SUA: scutul republicii. Cu toate acestea, Wolfers nu îl citează pe Lippmann, așa cum indică Buzan și Ayoob, ci interpretează definiția pe care acesta o dă securității, echivalând interesele vitale/legitime ale unui stat cu valorile sale fundamentale, susținând că această definiție se referă implicit la un grad de protecție a acestor valori care poate varia de la lipsa aproape completă a protecției acestora și, prin urmare, de la absența securității, la protecție lor cvasitotală și, prin urmare, la securitate aproape totală și considerând că, pe timp de pace, securitatea reprezintă capacitatea unui stat de a descuraja un război împotriva $\mathrm{sa}^{26} \cdot \mathrm{Cu}$ excepția existenței unor grade de securitate, interpretarea dată de Wolfers nu contravine perspectivei lui Lippmann asupra securității. Incompatibilitatea gradualității securității cu ideile lui Lippmann este o consecință a faptului că sensul maximal pe care acesta îl atribuie securității implică faptul că un stat dispune de securitate numai atunci când are puterea necesară pentru a-și proteja interesele vitale prin asumarea riscului unui război sau prin câștigarea unui război. În consecință, se poate spune că Lipmann consideră că, dacă puterea unui stat este insuficientă pentru a face acest lucru, statul respectiv nu dispune de mai puțină securitate, ci se află într-o situaţie de insecuritate. Rezultă că, pentru Lippmann, există doar securitate totală, orice se situează sub acest nivel fiind pur și simplu insecuritate.

Wolfers se referă și la aspectele implicite ale concepției lui Lippmann despre securitate, arătând că securitatea reprezintă pentru Lippmann o valoare pe care, dat fiind că există grade de securitate, un stat o poate deține într-o măsură mai mare sau mai mică și poate dori să o aibă într-o măsură mai mare sau mai mică; faptul că Wolfers atribuie aceste idei lui Lippmann rezultă din introducerea lor prin intermediul cuvântului $d e c i .{ }^{27}$ Aprofundând analiza acestor aspecte, Wolfers susține că securitatea este pentru Lippman doar una dintre valorile care pot fi promovate prin intermediul politicii externe, celelalte valori fiind puterea și bogăția. Se observă însă că Lippmann consideră că puterea este mijlocul prin care se obține securitatea, ceea ce înseamnă că el nu plasează puterea și securitatea pe același nivel și, prin urmare, că nu le consideră pe ambele ca fiind valori și, astfel, ca reprezentând obiective primordiale ale politicii externe. ${ }^{28}$

\footnotetext{
${ }^{26}$ Arnold Wolfers, „National Security as an Ambiguous Symbol”, pp. 484, 485, în Political Science Quarterly, vol. 67, nr. 4, 1952, pp. 481-502.

${ }^{27}$ Ibidem, p. 484.

${ }^{28}$ Ibidem, p. 484, „Securitatea este, deci, o valoare pe care o națiune o poate deține într-o măsură mai mare sau mai mică și pe care poate dori să o aibă într-o măsură mai mare sau mai mică”.
} 
Pentru a diferenția securitatea de putere și de bogăție, Wolfers indică într-un paragraf frecvent citat că ,securitatea, într-un sens obiectiv, măsoară absența amenințărilor la adresa valorilor dobândite, iar în sens subiectiv, absența fricii că astfel de valori vor fi atacate" 29 . Este posibil să se argumenteze că această caracterizare a securității are rolul de a explica definiția securității propusă de Lippmann, mai exact unele caracteristici implicite ale acesteia, astfel încât se poate spune că Wolfers nu o consideră ca fiind în mod necesar propria sa contribuție la definirea acestui concept. Asumând că analiza lui Wolfers urmărește să clarifice definiția lui Lippmann, acest citat ar trebui interpretat în sensul că, din punct de vedere obiectiv, securitatea se referă la faptul că un stat are puterea necesară pentru a risca un război pentru protejarea intereselor sale vitale sau pentru a câștiga un război la care participă în acest scop, în timp ce, din punct de vedere subiectiv, securitatea înseamnă că cetățenii nu se tem că statului lor îi lipsește puterea care să îi permită să riște un război pentru protejarea intereselor vitale sau să câștige un astfel de război. Astfel, în conformitate cu perspectiva lui Lippmann asupra securității pe care citatul menționat se presupune că ar trebui să o explice, amenințarea la care se referă Wolfers nu este riscul declanșării unui război sau războiul în sine, ci lipsa puterii care să permită unui stat să-şi asume cu prudență riscul unui război sau să îl câștige. Este, însă, posibilă și interpretarea acestui citat ca referindu-se la faptul că riscul declanşării unui război și războiul în sine reprezintă amenințări la adresa securităţii. ${ }^{30}$

Tot în conformitate cu perspectiva lui Lippmann asupra securității, care corelează în mod necesar securitatea cu cel mai ridicat grad posibil de obiectivitate a evaluării de către oamenii de stat a capacității statului de a-și asuma riscul unui război sau de a-l câștiga, sensul subiectiv al securității trebuie înțeles ca sentimentul generat în rândul populaţiei unui stat de o astfel de evaluare, în timp ce sensul obiectiv al acesteia ar trebui înțeles ca cea mai puțin subiectivă evaluare a puterii naționale pe care oamenii ar putea-o face. Prin urmare, distincția dintre sensul obiectiv și sensul subiectiv al securității la care se referă Wolfers nu ar trebui interpretată ca o distincție între o evaluare foarte bine justificată (sensul obiectiv) și o evaluare care este insuficient justificată (sensul subiectiv), ci ca o distincție între o evaluare foarte bine justificată și efectele sale în plan psihologic asupra celor care efectuează evaluarea. Cu toate acestea, Wolfers nu are această lectură a termenilor de obiectiv și de subiectiv, considerând în schimb că evaluarea subiectivă se opune celei obiective, prima distorsionând realitatea, iar cea de-a doua surprinzând-o cu exactitate. El ilustrează această diferență menționând că, după Primul Război Mondial, Franța a operat cu un sens subiectiv al securității, deoarece a exagerat riscul unui nou război cu Germania, în timp ce alte mari puteri din Liga Națiunilor

${ }^{29}$ Ibidem, p. 485.

${ }^{30}$ Ibidem, p. 485. 
au operat cu un sens obiectiv al securității pentru că au apreciat în mod corect că un astfel de risc era mult mai redus. Wolfers admite că o evaluare pur obiectivă a riscului declanșării unui război este imposibilă, motiv pentru care o astfel de evaluare ar putea fi obiectivă doar într-un sens relativ, idee care corespunde opiniei lui Lippmann că, în domeniul politicii externe, se poate vorbi doar despre acea obiectivitate la care oamenii pot ajunge și nu despre obiectivitate în sine. ${ }^{31}$

\section{Rezultate și concluzii}

Acest articol a oferit argumente în sprijinul ideii că binecunoscuta distincție operată de Wolfers între sensul obiectiv și cel subiectiv al securității, precum și descrierea securității din care această distincție face parte, au avut inițial rolul de a explica elemente implicite ale definiției date securității de către Lippmann, dar că, în cele din urmă, ele au generat o nouă perspectivă asupra securităţii. Acest lucru s-a întâmplat, deoarece Wolfers a prezentat în mod inexact opiniile lui Lippmann despre securitate, menționând că, pentru acesta, securitatea este o problemă care admite grade, că securitatea și puterea sunt valori similare în domeniul politicii externe și, cel mai important, că există posibilitatea ca securitatea să existe și atunci când are la bază o evaluare eronată și ca securitatea să desemneze absența, reală sau aparentă, a amenințărilor la adresa intereselor vitale. Prima interpretare eronată a ideilor lui Lippmann are ca rezultat faptul că ceea ce el consideră a fi insecuritate devine pentru Wolfers un grad mai redus de securitate, o interpretare care derivă din înțelegerea securității ca reprezentând o valoare și, în consecință, ca fiind ceva care poate fi posedat într-o măsură mai mare sau mai mică; în acest fel, perspectiva ontologică maximală asupra securității este înlocuită cu o viziune mult mai puțin exigentă asupra acestui concept care permite chiar și o înțelegere ontologică minimală a acestui concept prin intermediul căreia securitatea nu mai reprezintă doar o performanță deosebită, ci devine ceva mult mai ușor de obținut. A doua interpretare eronată a lui Lippmann este cea care face posibilă existența unor grade de securitate deoarece securitatea este considerată o valoarea de același tip ca și puterea și pentru că distribuirea inegală a puterii între state este prezentată ca o problemă evidentă. Această interpretare inadecvată transformă puterea dintr-un mijloc prin care se obține securitatea într-un scop ce poate fi dorit pentru el însuși, uneori chiar și în locul securității, astfel încât securitatea nu mai reprezintă în mod necesar scopul primordial al unui stat. În ceea ce privește ultima interpretare eronată a perspectivei lui Lippmann asupra securității, un prim aspect al acesteia este corelarea securității în principal cu elemente din afara statului, și anume cu amenințările la adresa acestuia, care provin din mediul internațional, și nu cu aspecte din interiorul statului, mai exact cu capacitatea acestuia de a face față cu

${ }^{31}$ Ibidem. 
succes amenințărilor respective; aspectul secund al acestei interpretări este acela că imprudența devine compatibilă cu securitatea, permițând astfel existența unei perspective cognitive nonmaximale asupra securității.

Prin urmare, pot fi formulate două răspunsuri la întrebarea de cercetare a acestui articol, primul fiind acela că, luând în considerare intenția lui Wolfers, definiția securităţii formulată de Lippmann a exercitat o influență majoră asupra definiției pe care acesta a dat-o securității, iar al doilea răspuns este acela că, având în vedere modul în care Wolfers interpretează definiția lui Lippmann, punctul de vedere al acestuia din urmă a influențat în mod semnificativ definiția propusă de Wolfers pentru conceptul de securitate. Altfel spus, din punct de vedere subiectiv, Wolfers a fost puternic influențat de Lippmann, dar, din punct de vedere obiectiv, influența lui Lippmann asupra sa a fost redusă. În concluzie, ambele răspunsuri la întrebarea de cercetare facilitează o mai bună înțelegere a concepției lui Wolfers și a lui Lippmann despre securitate, a relației dintre opiniile lor cu privire la definiția securității și a ceea ce este specific sensului pe care fiecare îl atribuie acestui concept, contribuind astfel la clarificarea primelor etape din evoluția studiilor de securitate.

\section{BIBLIOGRAFIE:}

1. AYOOB, Mohammed, ,Security in the Third World: the worm about to turn?", în International Affairs, vol. 60, nr. 1, 1984.

2. BALDWIN, David, „The Concept of Security”, în Review of International Studies, vol. 23, nr. 1, 1997.

3. BUZAN, Barry, People, States, and Fear. The National Security Problem in International Relations, Brighton, Wheatsheaf Books, 1983.

4. BUZAN, Barry, People, States, and Fear. An Agenda for International Security Studies in the Post-Cold War Era, Colchester, ECPR Press, 2009.

5. BUZAN, Barry; HANSEN, Lene, The Evolution of International Security Studies, Cambridge, Cambridge University Press, 2009.

6. DUNN CAVELTY, Myriam; MAUER, Victor, „Introduction”, în Myriam Dunn Cavelty; Victor Mauer (coord.), The Routledge Handbook of Security Studies, Londra, Routledge, 2010.

7. DUNN CAVELTY, Myriam; BALZACQ, Thierry, „Introduction”, în Myriam Dunn Cavelty, Thierry Balzacq (coord.), Routledge Handbook of Security Studies, ediția a 2-a, Londra, Routledge, 2017.

8. GOODRICH, Leland M., „U. S. Foreign Policy: Shield of the Republic by Walter Lippmann", în The American Political Science Review, vol. 37, nr. 5, 1943.

9. GUILHOT, Nicolas (coord.), The Invention of International Relations Theory: Realism, the Rockefeller Foundation, and the 1954 Conference on Theory, New York, Columbia University Press, 2011. 
10. HUGHES, Christopher W.; LAI, Yew Meng (coord.), Security Studies. A Reader, Londra, Routledge, 2011.

11. LIPPMANN, Walter, US foreign policy: Shield of the Republic, Boston, Little Brown and Company, 1943.

12. MALIN, James C., „U.S. Foreign Policy: Shield of the Republic by Walter Lippmann; America's Foreign Policies, Past and Present by Thomas A. Bailey", în Pacific Historical Review, vol. 12, nr. 4, 1943.

13. McDONALD, Matt, „Constructivism”, în PaulD. Williams, Matt McDonald (coord.), Security Studies. An Introduction, ediția a 3-a, Londra, Routledge, 2018.

14. PEOPLES, Columba; VAUGHAN-WILliAMS, Nick, Critical Security Studies. An Introduction, ediţia a 3-a, Londra, Routledge, 2021.

15. SMITH, Edward, "The Traditional Routes to Security. Realism and Liberalism", în Peter Hough, Andrew Moran, Bruce Pilbeam, Wendy Stokes (coord.), International Security Studies. Theory and Practice, ediția a 2-a, Londra, Routledge, 2021.

16. SMITH, Graham M., ,Into Cerberus' Lair: Bringing the Idea of Security to Light", în British Journal of Politics and International Relations, vol. 7, nr. 4.

17. SUMNER BENSON, Mary, „U.S. Foreign Policy: Shield of the Republic by Walter Lippmann; Collective Security: The Why and How, by Joseph H. Ball", în The Far Eastern Quarterly, vol. 3, nr. 3, 1944.

18. WILLIAMS, Robert E. Jr., „The Invention of International Relations Theory: Realism, the Rockefeller Foundation, and the 1954 Conference on Theory, Edited by Nicolas Guilhot", în Ethics and International Affairs, vol. 26, nr. 2, 2012.

19. WOLFERS, Arnold, „The Pole of Power and the Pole of Indifference”, în World Politics, vol. 4, nr. 1, 1951.

20. WOLFERS, Arnold, „National Security as an Ambiguous Symbol”, în Political Science Quarterly, vol. 67, nr. 4, 1952.

21. WOLFERS, Arnold, Discord and Cooperation. Essays on International Politics, Baltimore, The John Hopkins Press, 1962. 